
\title{
25 Research Square \\ Identification of ATFs in Human Breast Cancer by Integrated Bioinformatic Analysis
}

chenchen Geng

Qilu Hospital of Shandong University (Qingdao) https://orcid.org/0000-0002-7495-9068

Qian Pu

Qilu Hospital of Shandong University Qingdao

Shuxu Tian

Qingdao Women and Children's Hospital

Wenwen Geng

Qilu Hospital of Shandong University Qingdao

Haiyan Wang

The Third People's Hospital of Qingdao

Guanghui Zhao

Qilu Hospital of Shandong University Qingdao

Haidong Gao (D 15806661668@163.com )

Qilu Hospital of Shandong University Qingdao

\section{Research Article}

Keywords: Activating transcription factor, mRNA, Prognosis, Breast cancer, Database

Posted Date: October 26th, 2021

DOl: https://doi.org/10.21203/rs.3.rs-948401/v1

License: (c) (i) This work is licensed under a Creative Commons Attribution 4.0 International License.

Read Full License 


\section{Abstract}

Background: To obtain a thorough comprehension of the profile and prognosis of activating transcription factor (ATF) family members in breast cancer.

Method: We searched Oncomine, GEPIA, cBioPortal, Kaplan-Meier plotter, and CancerSEA databases to assess expression level, prognostic value, and functions of ATFs in breast cancer.

Results: In breast cancer, we found that the expression levels of genes like ATF1, ATF5, and ATF6, were higher than in normal tissues. While the expression levels of ATF3, ATF4, ATF7 were lower in the former than in the latter. Similarly, the ATFs protein expressions were consistent with this in the Human Protein Atlas database. High expressions of ATF2, ATF4, and ATF6-7 were associated with good relapse-free survival. Increased expressions of ATF4 and ATF7 had high overall survival. Conversely, the mRNA expression of ATF1 was negatively correlated with distant metastasis-free survival. Similarly, high expression of ATF2 had reduced post-progression survival.

Conclusions: ATF1 was a target of potential therapeutic interest for breast cancer, and ATF4 and ATF6-7 were potential prognostic factors in evaluating breast cancer.

\section{Introduction}

Breast cancer $(\mathrm{BrCa})$ is the most commonly diagnosed cancer among women and the second leading cause of cancer death in women worldwide [1]. Many factors, including environmental, biological, lifestyle, and genetic factors, are currently studied to understand the causes of $\mathrm{BrCa}$. BRCA $1 / 2$ genes mutations are the most common inherited mutations associated with $\mathrm{BrCa}$ [2]. Currently, the therapy of $\mathrm{BrCa}$ consists of surgery, radiation, chemotherapy, and hormone therapy [3]. According to different clinical subtypes of $\mathrm{BrCa}$, specific treatments would be chosen. As the field of $\mathrm{BrCa}$ advances, the application of immunotherapy increases and becomes a potential future therapy in patients with $\mathrm{BrCa}$. High heterogeneity is one of the characters of $\mathrm{BrCa}$, and a challenge to targeted treatment for $\mathrm{BrCa}$ [4]. Therefore, using genomics to discover new molecular markers or targets to achieve precise therapies has become a recent research trend.

Activating transcription factor (ATF) family members are expressed in various tissues and tumor cell lines, playing significant roles in tumorigenesis and tumor progression [5]. As transcription factors, ATFs regulate the expression of downstream genes involved in growth, survival, and apoptosis. ATFs primarily diversify in size, protein sequence, and biological function [6-8]. ATFs contain seven members (ATF1-7) and belong to activating transcription factor/CAMP responsive element binding (ATF/CREB) protein family $[9,10]$. All members share a typical basic-region leucine zipper (bZIP) element and bind target DNA with a consensus CRE (TGACGTCA) [11]. Based on previous studies, members of the ATF family were considered to participate in the progression, aggressiveness, and therapy resistance of $\mathrm{BrCa}$ [12]. At the same time, some molecules like ATF2, ATF3, ATF4 played an essential role in apoptosis [13-15]. However, the studies focused on the function of ATFs in BrCa were sporadic, and the systemic description 
was scarce. Thus, the molecular events in cancer require a thorough investigation of the databases. In this study, we mined some databases, used bioinformatic analysis to determine the expression profiles and prognostic significance of ATFs, and obtained a comprehensive understanding of ATFs in BrCa.

\section{Materials And Methods}

\section{Oncomine database analysis}

Oncomine gene expression array datasets (http://www.oncomine.org; an online cancer microarray database) were used to display mRNA expression levels of the ATFs in different cancers. The mRNA expression analysis of each gene was acquired from tumor specimens and normal tissues. Cut-off of $P$ value and fold change were set at 0.01 and 1.5 , respectively.

\section{GEPIA database analysis}

The GEPIA database (http://gepia.cancer-pku.cn/) is an online dataset based on the Cancer Genome Atlas (TCGA) (https://www.cancer.gov/tcga), which analyzed gene expression by comparing cancer specimens and paired normal tissues [16]. In the present study, the expression profiling of ATFs in BrCa and normal tissue and different pathological stages was demonstrated by GEPIA. Whether there were significantly different was defined with a cutoff $P<0.01$.

\section{Human protein atlas}

Human Protein Atlas (https://www.proteinatlas.org) is a free database containing immunohistochemistry straining of more than 11,200 unique proteins in normal tissues and cancers [17]. It was based on staining intensity and fractional quantity of stained cells to define different expression levels of ATFs between $\mathrm{BrCa}$ and normal tissues.

\section{Kaplan-Meier Plotter analysis}

Kaplan-Meier Plotter (http://kmplot.com/analysis/) includes gene expression and associated survival data provided by TCGA, Gene Expression Omnibus (GEO) [18] and the Cancer Biomedical Informatics Grid [19]. In this study, Kaplan-Meier Plotter was used for evaluating the prognostic value of ATFs in BrCa. Overall survival (OS), post-progression survival (PPS), distant metastasis-free survival (DMFS), and relapse-free survival (RFS) were included in this analysis by splitting patients into two clusters according to high and low expression levels, based on the median. We also presented the hazard ratio (HR) with a $95 \%$ confidence interval $(\mathrm{Cl})$ and log-rank $P$ value. Only the JetSet best probe set was used to assess gene expression. Patients' relative prognoses were denoted to the red and black line (high vs. low expression), respectively. Significance was assessed at the level of $P$ value less than 0.05 .

\section{cBioPortal database analysis}


The cBioPortal database (http://www.cbioportal.org) is a free database that offers visualization and analysis of multidimensional data of cancer genomics [20,21]. We explored genetic alterations of ATFs in the cBioPortal database based on $1084 \mathrm{BrCa}$ samples in TCGA. The genomic alterations included mutation and putative copy number alterations (CNAs), which were identified by genomic identification of significant targets in cancer (GISTIC). Enrichment analysis was performed of co-expression genes associated with ATFs inspected by cBioPortal. Gene enrichment was conducted by GO enrichment analysis and KEGG pathway enrichment analysis and visualized by the $R$ package ggplot2 ( $R$ version 3.6.3).

\section{CancerSEA analysis}

CancerSEA (http://biocc.hrbmu.edu.cn/CancerSEA/) is a web resource that helped to explore the cancer single-cell function. Human tumor single cell RNA-seq (scRNA-seq) data was integrated by three datasets, including the GEO database, ArrayExpress (https://www.ebi.ac.uk/arrayexpress/), and the Sequence Read Archive (https://www.ncbi.nlm.nih.gov/sra) [22] In this study, CancerSEA was used to analyze ATFs. The correlation analysis of ATFs and 14 function states, including DNA repair, DNA damage, apoptosis, angiogenesis, differentiation, epithelial-mesenchymal transition (EMT), inflammation, cell cycle, hypoxia, invasion, stemness, metastasis, quiescence, and proliferation, were studied.

\section{Results}

\section{ATFs transcript levels in BrCa patients}

We compared the transcript levels of ATFs in tumors and normal tissues by using Oncomine databases (Fig. 1). As showed, most cancers had high expression of ATFs, especially ATF3, ATF5, ATF6. While in BrCa, only ATF5, ATF6, and ATF7 were upregulated in cancer tissues. In Curtis's dataset [23], ATF5 was significantly higher in medullary breast carcinoma than normal tissue (fold change=1.977) (Table 1). As reported by Richardson, high ATF5 expression was found in ductal breast carcinoma compared with normal tissues (fold change=1.760) [24]. Likewise, in Curtis's dataset, ATF6 was overexpressed in multiple types of $\mathrm{BrCa}$, including tubular breast carcinoma with a fold change of 1.780 , ductal breast carcinoma in situ with a fold change of 1.751, invasive ductal and invasive lobular breast carcinoma with a fold change of 1.731 , breast carcinoma with a fold change of 1.630 , medullary breast carcinoma with a fold change of 1.618, invasive ductal breast carcinoma with a fold change of 1.613 , invasive lobular breast carcinoma with a fold change of 1.591, and invasive breast carcinoma with a fold change of 1.570, compared with normal breast tissues [23]. Furthermore, Ma et al indicated that ATF6 was overexpressed in invasive breast carcinoma in situ epithelia with fold change $=1.750$, ductal breast carcinoma in situ epithelia with fold change $=1.986$, versus normal tissues [25]. Similarly, Radvanyi et al showed that ATF6 had increased expression in invasive ductal breast carcinoma (fold change=4.518), invasive lobular breast carcinoma (fold change $=4.377$ ), and invasive mixed breast carcinoma (fold change= 6.122) [26]. In TCGA breast statistics, ATF6 had increased expression in multiple types of $\mathrm{BrCa}$, including invasive lobular breast carcinoma (fold change $=1.593$ ), invasive breast carcinoma (fold 
change $=1.666$ ), invasive ductal and lobular carcinoma (fold change $=1.974)$, mixed lobular and ductal breast carcinoma (fold change $=1.574$ ), and invasive ductal breast carcinoma (fold change $=1.562$ ) versus normal samples. Compared with normal tissue, ATF7 was overexpressed in invasive ductal and lobular carcinoma (fold change $=1.557$ ). Ma et al stated that high expression of ATF7 could be seen in invasive breast carcinoma in situ epithelia (fold change $=1.616$ ) and ductal breast carcinoma in situ epithelia (fold change $=1.918$ ) versus normal tissues [25].

\section{The relationship between ATFs Transcript Levels and pathology of $\mathrm{BrCa}$}

After searching the GEPIA dataset, we found that higher expression levels of ATF1, ATF5, and ATF6 were in BrCa. Conversely, lower expression levels of ATF3, ATF4, ATF7 were in BrCa versus normal tissues, although a statistically significant difference was observed on ATF3 only (Fig. 2). Also, the association between the tumor stages of $\mathrm{BrCa}$ and the expression of ATFs was analyzed. As showed in Fig. 3, there were no significantly difference of the mRNA expression levels of ATF1 $(P=0.0461)$, ATF2 $(P=0.00719)$, ATF3 $(P=0.0109)$, ATF4 $(P=0.716)$, ATF5 $(P=0.716)$, ATF6 $(P=0.716)$ and ATF7 $(P=0.00598)$ in different stages of $\mathrm{BrCa}$ (stages I to IV).

The expression levels of ATFs proteins in $\mathrm{BrCa}$ and paracarcinoma tissues by immunohistochemical staining were retrieved via the Human Protein Atlas database. The results were shown in Fig. 4. It showed higher protein levels of ATF1, ATF5, and ATF6 were in BrCa tissues compared to normal tissue. In contrast, lower expression levels of ATF3, ATF4, ATF7 were in BrCa tissues, consistent with mRNA expression levels.

\section{The prognostic value of ATFs expression in BrCa patients}

Through the Kaplan-Meier plotter, we analyzed the correlation between the ATFs expression levels and the prognosis of BrCa patients. We estimated OS, RFS, PPS, and DMFS by Kaplan-Meier curves. As showed in Fig. 5, high expression of ATF2(HR, 1.31; $95 \% \mathrm{Cl}, 1.18$ to 1.45), ATF4(HR, 1.13; 95\% Cl, 1.02-1.25), ATF6(HR,0.76; $95 \% \mathrm{Cl}, 0.65$ to 0.88$)$, and ATF7(HR,0.76; $95 \% \mathrm{Cl}, 0.66$ to 0.89$)$ had high RFS. High expression of ATF7(HR,0.74; $95 \% \mathrm{Cl}, 0.56$ to 0.96$)$ and had ATF4(HR, 1.23; $95 \% \mathrm{Cl}, 1.01$ to 1.48) high OS. In addition, high ATF1 expression ( $\mathrm{HR}, 0.79 ; 95 \% \mathrm{Cl}, 0.68$ to 0.92$)$ had worse DMFS. Likewise, high ATF2 expression (HR,1.35; 95\% $\mathrm{Cl}, 1.07-1.71 ; P=0.012)$ had reduced PPS. The other ATFs had no obvious prognostic significance on survival.

\section{The changes of ATFs and predicted function and pathways of ATFs and neighbor genes}

To analyze the alterations and correlations of ATFs, we downloaded the data using the cBioPortal for Cancer Genomics platform. There were 17\% out of the samples in BrCa had altered ATFs (Fig. 6A). Genetic amplification was the most common change of ATFs, especially in ATF3(8\%) and ATF6(10\%). Correlations of ATFs with each other were calculated and showed in Fig. 6B. Both positive and negative correlations were visualized. ATF7 had the highest positive correlation with ATF1 and ATF2 with Pearson's coefficient of $0.45,0.45$, respectively. Additionally, ATF7 had the strongest negative correlation 
with ATF4 (Pearson's coefficient $=-0.41$ ). Meanwhile, the closest relation was demonstrated between ATF7 and other ATFs with a median Pearson's coefficient of 0.41 .

Then, we applied the GO enrichment analysis and KEGG pathway analysis to predict the functions of ATFs and the genes mutated with ATFs (Fig. 7). GO enrichment analysis included cellular components, biological processes, and molecular function. Most of the genes frequently altered with ATFs were involved in ubiquitin-like protein transferase activity, regulatory RNA binding, ubiquitin-protein transferase activity, histone methyltransferase complex, transcriptionally active chromatin, nuclear speck, covalent chromatin modification, nucleosome disassembly, and histone modification. Second, we found that lysine degradation and transcriptional misregulation in cancer were associated with the functions of ATFs alterations by KEGG pathway analysis.

\section{The functions of ATFs in single BrCa cell}

By searching in CancerSEA, we found the primary relationship between ATFs and cell function was apoptosis (Fig. 8A). Chung et al showed that high ATFs mRNA levels positively correlated with quiescence (Spearman's coefficients, $0.39 ; \mathrm{P}<0.01$ ) and apoptosis (Spearman's coefficients, $0.33 ; \mathrm{P}<0.01$ ) (Fig. 8B) [27]. Jordan et al showed that ATFs were also positively associated with apoptosis (Spearman's coefficients, $0.41 ; P<0.01$ ) (Fig. $8 \mathrm{C}$ ) [28]. In different cell groups, the ATFs were positively related to apoptosis (Spearman's coefficients, $0.49 ; \mathrm{P}<0.01$ ) and DNA damage (Spearman's coefficients, 0.47; $P<0.01$ ), while negatively related to stemness (Spearman's coefficients, $-0.35 ; P<0.01$ ) and differentiation (Spearman's coefficients, $-0.33 ; \mathrm{P}<0.01)$ (Fig. 8D) [27].

\section{Discussion}

As members of the ATF/CREB protein family, activated ATFs bind to CREs and promote CRE-mediated multiple genes transcription, which is involved in cell growth, inflammation, proliferation, apoptosis, and DNA damage response [29-31]. Despite some studies had confirmed the expression and function of ATFs in $\mathrm{BrCa}$, a thorough, comprehensive analysis of ATFs has not been performed. As far as we know, this was the first bioinformatics of the ATF family, which dug out the mRNA expression, prognostic values, and single cell function. We hope that the results of this study could be beneficial for clinical research.

ATF1 was confirmed to regulate downstream target genes functioned as growth and survival [3234], and involved in tumorigenesis in some cancers, including colorectal cancer [35], prostate cancer [36], and clear cell sarcoma [37]. However, there is limited information about ATF1 and BrCa. Houvras Y et al reported that ATF1 could interact with BRCA1 leading to the maintenance of genome integrity after DNA damage [38]. In the study of Jones DT and his colleges, high expression of ATF1 in invasive ductal carcinoma (IDC) could induce VEGF-stimulated angiogenesis in vitro. ${ }^{39}$ In the current study, higher ATF1 expression was in $\mathrm{BrCa}$ compared to normal tissues by searching the Oncomine and GEPIA. This finding was consistent with the protein expression of ATF1 obtained from the Human Protein Atlas. High ATF1 expression had worse DMFS in BrCa patients analyzed by the Kaplan-Meier plotter. 
ATF2 regulated many genes involved in the various cellular signal pathway [39]. A series of studies had focused on ATF2 and BrCa. In murine mammary cancer, ATF2 was critical to induce FOXP3 exerted an effect and FOXP3-mediated apoptosis [40], and ATF2 gene knockout mice were more likely to develop $\mathrm{BrCa}$ [41]. It was also reported that lower ATF2 mRNA level was in human BrCa compared to normal tissues [41]. Thus, it can be seen that ATF2 tended to have a tumor-suppressive function in BrCa. Nevertheless, some studies concluded opposite results. It was reported that ATF2 could increase the expression of matrix metalloproteinase 13 (MMP13), which had an essential role in bone metastasis of $\mathrm{BrCa}[42,43]$. Moreover, ATF2 could promote proliferation by inducing the transcriptional activation of cyclin A [44]. In tumor development and metastasis progress, the complex consisted of ATF2 and c-Fos, and c-Jun also participated by regulating the induction of cyclooxygenase-2(COX2) [45]. Increased protein expression of ATF2 measured by immunohistochemistry $(\mathrm{IHC})$ was associated with prolonged survival [46]. In our report, the mRNA and protein level of ATF2 had no significant difference in BrCa versus normal tissues. In comparison, high ATF2 expression was associated with good RFS but poor PPS. Our findings were consistent with the previous result that whether ATF2 played cancer-suppressive or cancer-promoting function depended on cancer stage progression $[47,48]$.

ATF3 played a dual role, either repressing or activating in transcription depended on binding molecules [49-52]. As an adaptive-response gene, in quiescent cells, the expression of ATF3 was low while under stressful conditions including ischemia, hypoxia, and injury, it would increase [53,54]. It was also reported as an oncogene or suppressor in different tumor models [55]. The location of the ATF3 gene is in the 1q amplicon of the chromosome, which is the most prone to the amplified region in $\mathrm{BrCa}$ and the second-largest amplified area in solid tumors [56]. In this study, we also found genetic amplification in $8 \%$ of ATF3. Through the upregulation of the TGF $\beta$ pathway or WNT/ $\beta$-catenin pathway, ATF3 is a protooncogene in $\mathrm{BrCa}[57,58]$. Cao et al concluded that high expression of ATF3 would lead to poor OS in breast cancer [59]. Some studies pointed out that through promoting cell cycle progression and preventing apoptosis, the overexpression of ATF3 could participate in resistance to radiotherapy [60], however, several studies showed differences. Hasim et al noted that high expression of ATF3 could improve OS in response to chemotherapy [61]. The previous study has pointed that ATF3 could bind to and stabilize p53 to promote apoptosis [62]. Our finding showed significantly lower mRNA and protein levels of ATF3 in BrCa compared to normal tissues, and we speculate that ATF3 could suppress BrCa. However, there was no prognostic significance on survival.

ATF4 played a significant role in regulating genes involved in cell stress and induced by PKR-like ER kinase (PERK), an endoplasmic reticulum (ER) sensor. It would overcome hypoxic and ischemic stress during tumor progression, proliferate, and metastasis by upregulating ATF4 to promote cancer survival [63]. Based on the above reason, ATF4 was proposed as a promoting factor for the pathogenesis and development of $\mathrm{BrCa}$. Some studies also revealed that ATF4 could regulate the expression of specific genes to promote $\mathrm{BrCa}$ metastasis [64,65]. Higher expression of ATF4 was found in BrCa than normal tissue and associated with lymph node metastases $[66,67]$. Meanwhile, high expression of ATF4 mRNA tended to poor prognosis in $\mathrm{BrCa}[67,68]$. Other studies reported opposite results. Zong et al found that loss of ATF4 could enhance survival, and over-expressing ATF4 could promote radiation-induced 
apoptosis in MCF7 cells [69]. The current study also found lower mRNA and protein levels of ATF4 in $\mathrm{BrCa}$, compared to normal tissues. Moreover, high ATF4 would lead to long RFS in BrCa patients.

ATF5 was widely present in many tissues and permanently restricted to epithelial cells. In the breast, it was expressed mainly by the luminal ductal epithelium [70]. Under stress, ATF5 could promote the survival of cancer cells and play a critical role in multiple cellular activities, which included apoptosis, survival, growth, and autophagy by regulating specific genes [71,72]. ATF5 was considered as an antiapoptotic factor, and if loss of function would cause apoptosis [73]. It was also found that ATF5 knockdown could inhibit aggressiveness and growth while triggering massive apoptosis of $\mathrm{BrCa}[70,74]$. ATF5 upregulated growth response factor 1 (Egr-1) and BCL-2 to promote the cell survival of $\mathrm{BrCa}[75,76]$. There is a significant difference in ATF5 between neoplasms and normal tissues, especially in adenocarcinomas. Monaco et al reported that high expression of ATF5 also existed in $\mathrm{BrCa}$ [77]. Similarly, we found higher mRNA and protein levels of ATF5 in BrCa than normal tissues in our study. Though ATF5 was critical in $\mathrm{BrCa}$ carcinogenesis, which indicated ATF5 might be a target for BrCa therapy, it was not detrimental to survival in current studies as far as we know.

ATF6 is currently the most studied family member because it is one of the three prominent endoplasmic reticulum stress sensors. ER stress plays an essential role during the various stages of cancer progression. Its activation is associated with highly aggressive cancers [78,79]. In $\mathrm{BrCa}$, researchers reported that ER stress had an essential impact on oncogenic, cancer-promoting, and resistance to therapy [80]. The ER stress triggered unfolded protein response (UPR) to restore metabolic and protein processing functions. Once UPR occurred, ATF6 moved to the Golgi apparatus and been sheared into an active fragment and transported into the nucleus subsequently to regulate target genes expression [81]. Based on the above discussion, ATF6 increased in many cancers, including colorectal cancer, hepatocellular cancer, and BrCa. Sicari et al concluded that ATF6 was essential for viability and invasion phenotypes in triple-negative breast cancer (TNBC) cells [82]. In our study, these results were similar to ours. ATF6 was higher expressed in BrCa than normal tissues. Interestingly, patients with high ATF6 performed better RFS rates. We speculated that ATF6 might also perform a different role in cancer progression as ATF2 played.

ATF7 has the most similar structure among the ATF family with ATF2 [83,84]. The distribution of ATF7 in tissues was also vided as ATF2 [84,85]. Likewise, ATF7 participated in cell activity by forming complex c with c-Jun, Fra2, or c-Fos [84,86]. ATF7 was highly expressed in hepatocellular carcinoma, promoting cell proliferation and suppressing apoptosis by binding with heat shock protein A member 1B (HSPA1B) [87]. There was a negative association between ATF7 expression and pathological stage in colorectal cancer while the positive correlation with OS and PFS [88]. Studies of ATF7 in BrCa were scarce. We found that lower expression of ATF7 was in BrCa than in normal tissues in this study. Similarly, high expression predicted better OS and RFS.

\section{Conclusion}


We systematically analyzed the association between expression and prognosis of the ATFs in BrCa in this study. The results showed that high expression of ATF1 might be necessary to BrCa progression and associated with poor survival. ATF2 played either suppressive or promoting function depended on cancer stage progression. Expression of ATF4, ATF6, and ATF7 had a significant positive correlation with survival. As mentioned above, we speculated that ATF1 was a target of potential therapeutic interest for $\mathrm{BrCa}$, and ATF4 and ATF6-7 were potential prognostic factors in evaluating BrCa. However, these results were concluded based on bioinformatics. Further validation of this hypothesis by experimental verification is required.

\section{Declarations}

\section{Acknowledgments}

Not applicable.

\section{Authors' contributions}

CG, QP, and ST were responsible for the design of the study, collection of databases, and drafted the manuscript. WG and HW performed the statistical analysis and analyzed the data. HG and GZ revised the manuscript. All authors read and approved the final version of the manuscript.

\section{Funding}

Not applicable.

\section{Availability of data and materials}

All data generated or analyzed during this study are included in this published article.

\section{Ethics approval and consent to participate}

This study was approved by the Ethics Committee of Qilu Hospital and conformed with the Declaration of Helsinki. As the datasets were collected from published literature, informed consent was obtained from patients.

\section{Consent for publication}

Not applicable.

\section{Competing interests}

The authors declare that they have no competing interests.

\section{Author details}


${ }^{1}$ Department of Ultrasound, Qilu Hospital (Qingdao), Cheeloo College of Medicine, Shandong University, No.758 Hefei Road, Qingdao 266035, China. ${ }^{2}$ Department of Breast Surgery, Qilu Hospital (Qingdao), Cheeloo College of Medicine, Shandong University, No.758 Hefei Road, Qingdao 266035, China.

${ }^{3}$ Department of Gynecology, Qingdao Women and Children's Hospital, Qingdao University, No.8 Tongfu Road, Qingdao 266034, China. ${ }^{4}$ Department of Clinical Laboratory, Affiliated Qingdao Third People's Hospital, Qingdao University, No.29 Yongping Road, Qingdao 266041, China. ${ }^{5}$ Medical Laboratory Center, Qilu Hospital (Qingdao), Cheeloo College of Medicine, Shandong University, No.758 Hefei Road, Qingdao 266035, China.

\section{References}

1. Porter PL. Global trends in breast cancer incidence and mortality. Salud Pública Méx. 2009;51(Suppl 2): s141-6. https://doi.org/10.1590/s0036-36342009000800003.

2. Easton DF. How many more breast cancer predisposition genes are there? Breast Cancer Res. 1999; 1(1): 14-7. https://doi.org/10.1186/bcr6.

3. Fan S, Yang Z, Ke Z, Huang K, Liu N, Fang X, et al. Downregulation of the long non-coding RNA TUG1 is associated with cell proliferation, migration, and invasion in breast cancer. Biomed Pharmacother. 2017; 95:1636-43. https://doi.org/10.1016/j.biopha.2017.09.076.

4.Berruti A, Brizzi MP, Generali D, Ardine M, Dogliotti L, Bruzzi P, et al. Presurgical systemic treatment of nonmetastatic breast cancer: facts and open questions. Oncologist.2008; 13(11):1137-

48. https://doi.org/10.1634/theoncologist.2008-0162.

5. Hai T, Hartman MG. The molecular biology and nomenclature of the activating transcription factor/cAMP responsive element binding family of transcription factors: activating transcription factor proteins and homeostasis. Gene. 2001;273(1):1-11. https://doi.org/10.1016/S0378-1119(01)00551-0.

6. Ghosh SK, Gadiparthi L, Zeng ZZ, Bhanoori M, Tellez C, et al. ATF-1 mediates protease-activated receptor-1 but not receptor tyrosine kinase-induced DNA synthesis in vascular smooth muscle cells. J Biol Chem.2002;277(24): 21325-31. https://doi.org/10.1074/jbc.M201608200.

7. Laag E, Majidi M, Cekanova M, Masi T, Takahashi T, Schuller HM. NNK activates ERK $1 / 2$ and CREB/ATF-1 via beta-1-AR and EGFR signaling in human lung adenocarcinoma and small airway epithelial cells. Int J Cancer. 2006; 119(7): 1547-52. https://doi.org/10.1002/ijc.21987.

8. Jean D, Tellez C, Huang S, Davis DW, Bruns CJ, McConkey DJ, et al. Inhibition of tumor growth and metastasis of human melanoma by intracellular anti-ATF-1 single chain Fv fragment. Oncogene. 2000;19(22): 2721-30. https://doi.org/10.1038/sj.onc.1203569. 
9. Hai T, Wolfgang CD, Marsee DK, Allen AE, Sivaprasad U. ATF3 and stress responses. Gene Expr.1999;7:321-35.

10. Thompson MR, Xu D, Williams BR. ATF3 transcription factor and its emerging roles in immunity and cancer.J Mol Med (Berl).2009;87(11):1053-60. https://doi.org/10.1007/s00109-009-0520-x.

11. Zhou H, Li N, Yuan Y, Jin YG, Guo H, Deng W, et al. Activating transcription factor 3 in cardiovascular diseases: a potential therapeutic target. Basic Res Cardiol. 2018;113(5):37. https://doi.org/10.1007/s00395-018-0698-6.

12. Harding HP, Novoa I, Zhang Y, Zeng H, Wek R, Schapira M, et al. Regulated translation initiation controls stress-induced gene expression in mammalian cells. Mol Cell. 2000; 6(5):1099-108. https://doi.org/10.1016/S1097-2765(00)00108-8.

13. Kim P, Scott MR, Meador-Woodruff JH. Dysregulation of the unfolded protein response (UPR) in the dorsolateral prefrontal cortex in elderly patients with schizophrenia. Mol Psychiatry. 2021;26(4):132131. https://doi.org/10.1038/s41380-019-0537-7.

14. Xiao L, Rao JN, Zou T, Liu L, Marasa BS, Chen J, et al. Polyamines regulate the stability of activating transcription factor-2 mRNA through RNA-binding protein HuR in intestinal epithelial cells. Mol Biol Cell. 2007;18(11):4579-90. https://doi.org/10.1111/j.1365-2966.2004.08045.x.

15. Chüeh AC, Tse JWT, Dickinson M, loannidis P, Jenkins $L$, Togel $L$, et al. ATF3 Repression of BCL-XL Determines Apoptotic Sensitivity to HDAC Inhibitors across Tumor Types. Clin Cancer Res. 2017;23(18):5573-84. https://doi.org/10.1158/1078-0432.CCR-17-0466.

16. Tang Z, Li C, Kang B, Gao G, Li C, Zhang Z. GEPIA: a web server for cancer and normal gene expression profiling and interactive analyses. Nucleic Acids Res. 2017;45(W1): w98-102. https://doi.org/10.1093/nar/gkx247.

17. Asplund A, Edqvist PHD, Schwenk JM, Pontén F. Antibodies for profiling the human proteome-The Human Protein Atlas as a resource for cancer research. Proteomics. 2012;12(13):2067-77. https://doi.org/10.1002/pmic.201100504.

18. Edgar R, Domrachev M, Lash AE. Gene expression omnibus: NCBI gene expression and hybridization array data repository. Nucleic Acids Res. 2002;30(1):207-10. https://doi.org/ 10.1093/nar/30.1.207.

19. von Eschenbach AC, Buetow K. Cancer informatics vision: CaBIG. Cancer Inform. 2007; 2:224. https://doi.org/10.1177/117693510600200013.

20. Cerami E, Gao J, Dogrusoz U, Gross BE, Sumer SO, Aksoy BA, et al. The cBio cancer genomics portal: an open platform for exploring multidimensional cancer genomics data.Cancer Discov. 2012; 2(5):4014. https://doi.org/10.1158/2159-8290.CD-12-0095. 
21. Gao J, Aksoy BA, Dogrusoz U, Dresdner G, Gross B, Sumer So, et al. Integrative analysis of complex cancer genomics and clinical profiles using the cBioPortal. Sci Signal. 2013; 6(269):pl1. https://doi.org/ 10.1126/scisignal.2004088.

22. Yuan H, Yan M, Zhang G, Liu W, Deng C, Liao G, et al. CancerSEA: A cancer single-cell state atlas. Nucleic Acids Res. 2019; 47 (D1): D900-8. https://doi.org/ 10.1093/nar/gky939.

23. Curtis C, Shah SP, Chin SF, Turashvili G, Rueda OM, Dunning MJ, et al. The genomic and transcriptomic architecture of 2,000 breast tumours reveals novel subgroups. Nature.2012;486 (7403):346-52. https://doi.org/0.1038/nature10983.

24. Richardson AL, Wang ZC, De Nicolo A, Lu X, Brown M, Miron A, et al. X chromosomal abnormalities in basal-like human breast cancer. Cancer Cell. 2006;9(2):121-

32. https://doi.org/10.1016/j.ccr.2006.01.013.

25. Ma XJ, Dahiya S, Richardson E, Erlander M, Sgroi DC. Gene expression profiling of the tumor microenvironment during breast cancer progression. Breast Cancer Res.2009;11(1):

R7. https://doi.org/10.1186/bcr2222.

26. Radvanyi L, Singh-Sandhu D, Gallichan S, Lovitt C, Pedyczak A, Mallo G, et al. The gene associated with trichorhinophalangeal syndrome in humans is overexpressed in breast cancer. Proc Natl Acad Sci. 2005;102(31)11005-10. https://doi.org/10.1016/S0304-4017(96)01026-6.

27. Chung W, Eum HH, Lee HO, Lee KM, Lee HB, Kim KT, et al. Single-cell RNA-seq enables comprehensive tumor and immune cell profiling in primary breast cancer. Nat Commun.2017; 8: 15081. https://doi.org/10.1038/ncomms15081.

28. Jordan NV, Bardia A, Wittner BS, Benes C, Ligorio M, Zheng Y, et al. HER2 expression identifies dynamic functional states within circulating breast cancer cells. Nature,2016; 537(7618): 1026. https://doi.org/10.1038/nature19328.

29. Sakamoto K, Karelina K, Obrietan K. CREB: a multifaceted regulator of neuronal plasticity and protection. J Neurochem. 2011;116(1): 1-9. https://doi.org/10.1111/j.1471-4159.2010.07080.x.

30. Lopez-Bergami P, Lau E, Ronai Z. Emerging roles of ATF2 and the dynamic AP1 network in cancer. Nat Rev Cancer. 2010;10(1):65-76. https://doi.org/10.1038/nrc2846.

31. Watson G, Ronai Z, Lau E. ATF2, a paradigm of the multifaceted regulation of transcription factors in biology and disease. Pharmacol Res. 2017; 119:347-57. https://doi.org/10.1016/j.phrs.2017.02.004.

32. Ghosh SK, Gadiparthi L, Zeng ZZ, Bhanoori M, Tellez C, Bar-Eli M, et al. ATF-1 mediates proteaseactivated receptor-1 but not receptor tyrosine kinase-induced DNA synthesis in vascular smooth muscle cells. J Biol Chem. 2002;277(24): 21325-31. https://doi.org/10.1074/jbc.M201608200. 
33. Laag E, Majidi M, Cekanova M, Masi T, Takahashi T, Schuller HM. NNK activates ERK1/2 and CREB/ATF-1 via beta-1-AR and EGFR signaling in human lung adenocarcinoma and small airway epithelial cells. Int J Cancer.2006;119(7): 1547-52. https://doi.org/10.1002/ijc.21987.

34. Jean D, Tellez C, Huang S, Davis DW, Bruns CJ, McConkey DJ, et al. Inhibition of tumor growth and metastasis of human melanoma by intracellular anti-ATF-1 single chain Fv fragment. Oncogene. 2000;19(22): 2721-30. https://doi.org/ 10.1038/sj.onc.1203569.

35. Wang $\mathrm{H}$, Zhu Y, Chen $\mathrm{H}$, Yang $\mathrm{N}$, Wang $X$, Li B, et al. Colorectal cancer risk variant rs 7017386 modulates two oncogenic IncRNAs expression via ATF1-mediated long-range chromatin loop. Cancer Lett. 2021;518: 140-51. https://doi.org/ 10.1016/j.canlet.2021.07.021.

36. Decker AM, Decker JT, Jung Y, Cackowski FC, Daignault-Newton S, Morgan TM, et al. Adrenergic Blockade Promotes Maintenance of Dormancy in Prostate Cancer Through Upregulation of GAS6. Transl Oncol. 2020;13(7): 100781. https://doi.org/10.1016/j.tranon.2020.100781.

37. Panza E, Ozenberger BB, Straessler KM, Barrott JJ, Li L, Wang Y, et al. The clear cell sarcoma functional genomic landscape. J Clin Invest. 2021;131(15). https://doi.org/10.1172/JCl146301.

38. Houvras Y, Benezra M, Zhang H, Manfredi JJ, Weber BL, Licht JD. BRCA1 physically and functionally interacts with ATF1. J Biol Chem. 2000;275(46):36230-7. https://doi.org/10.1074/jbc.M002539200.

39. Jones DT, Lechertier T, Mitter R, Herbert JM, Bicknell R, Jones JL et al. Gene expression analysis in human breast cancer associated blood vessels. PLoS One.

2012;7(10):e44294. https://doi.org/10.1371/journal.pone.0044294.

39. Lopez-Bergami P, Lau E, Ronai Z. Emerging roles of ATF2 and the dynamic AP1 network in cancer. Nat Rev Cancer. 2010;10(1):65-76.https://doi.org/ 10.1038/nrc2681.

40. Liu Y, Wang Y, Li W, Zheng P, Liu Y. Activating transcription factor 2 and c-Jun-mediated induction of FoxP3 for experimental therapy of mammary tumor in the mouse. Cancer Res. 2009;69(14):5954-60. https://doi.org/10.1158/0008-5472.CAN-09-0778.

41. Maekawa T, Shinagawa T, Sano Y, Sakuma T, Nomura S, Nagasaki K et al. Reduced levels of ATF-2 predispose mice to mammary tumors. Mol Cell Biol. 2007;27(5):1730-44.

https://doi.org/10.1128/MCB.01579-06.

42. Tsuchimochi K, Otero M, Dragomir CL, Plumb DA, Zerbini LF, Libermann TA et al. GADD45beta enhances Col10a1 transcription via the MTK1/MKK3/6/p38 axis and activation of C/EBPbeta-TAD4 in terminally differentiating chondrocytes. J Biol Chem. 2010;285(11):8395407. https://doi.org/10.1074/jbc.M109.038638.

43. Nannuru KC, Futakuchi M, Varney ML, Vincent TM, Marcusson EG, Singh RK. Matrix metalloproteinase (MMP)-13 regulates mammary tumor-induced osteolysis by activating MMP9 and 
transforming growth factor-beta signaling at the tumor-bone interface. Cancer Res. 2010;70(9):3494504. https://doi.org/10.1158/0008-5472.CAN-09-3251.

44. van Dam H, Castellazzi M. Distinct roles of Jun : Fos and Jun : ATF dimers in oncogenesis. Oncogene. 2001;20(19):2453-64. https://doi.org/10.1038/sj.onc.1204239.

45. Subbaramaiah K, Norton L, Gerald W, Dannenberg AJ. Cyclooxygenase-2 is overexpressed in HER2/neu-positive breast cancer: evidence for involvement of AP-1 and PEA3. J Biol Chem. 2002;277(21):18649-57. https://doi.org/10.1074/jbc.M111415200.

46. Knippen S, Loning T, Muller V, Schroder C, Janicke F, Milde-Langosch K. Expression and prognostic value of activating transcription factor 2 (ATF2) and its phosphorylated form in mammary carcinomas. Anticancer Res. 2009;29(1):183-9.

47. Su B, Tang HL, Deng M, Liao QJ, Zeng X, Zhang WL et al. Stage-associated dynamic activity profile of transcription factors in nasopharyngeal carcinoma progression based on protein/DNA array analysis. OMICS. 2011;15(1-2):49-60. https://doi.org/10.1089/omi.2010.0055.

48. Vlahopoulos SA, Logotheti S, Mikas D, Giarika A, Gorgoulis V, Zoumpourlis V. The role of ATF-2 in oncogenesis. Bioessays. 2008;30(4):314-27. https://doi.org/10.1002/bies.20734.

49. Hai T, Curran T. Cross-family dimerization of transcription factors Fos/Jun and ATF/CREB alters DNA binding specificity. Proc Natl Acad Sci U S A. 1991;88(9):3720-4. https://doi.org/10.1073/pnas.88.9.3720.

50. Hai TW, Liu F, Coukos WJ, Green MR. Transcription factor ATF cDNA clones: an extensive family of leucine zipper proteins able to selectively form DNA-binding heterodimers. Genes Dev. 1989;3(12B):208390. https://doi.org/ 10.1101/gad.3.12b.2083.

51. Hsu JC, Laz T, Mohn KL, Taub R. Identification of LRF-1, a leucine-zipper protein that is rapidly and highly induced in regenerating liver. Proc Natl Acad Sci U S A. 1991;88(9):3511-5. https://doi.org/10.1073/pnas.88.9.3511.

52. Nilsson M, Toftgard R, Bohm S. Activated Ha-Ras but not TPA induces transcription through binding sites for activating transcription factor $3 /$ Jun and a novel nuclear factor. J Biol Chem. 1995;270(20):12210-8. https://doi.org/10.1074/jbc.270.20.12210.

53. Hai T, Wolford CC, Chang YS. ATF3, a hub of the cellular adaptive-response network, in the pathogenesis of diseases: is modulation of inflammation a unifying component? Gene Expr. 2010;15(1):1-11. https://doi.org/10.3727/105221610x12819686555015.

54. Lu D, Wolfgang CD, Hai T. Activating transcription factor 3, a stress-inducible gene, suppresses Rasstimulated tumorigenesis. J Biol Chem. 2006;281(15):10473-81. https://doi.org/10.1074/jbc.M509278200. 
55. Borgoni S, Sofyali E, Soleimani M, Wilhelm H, Muller-Decker K, Will R et al. Time-Resolved Profiling Reveals ATF3 as a Novel Mediator of Endocrine Resistance in Breast Cancer. Cancers (Basel). 2020;12(10). https://doi.org/10.3390/cancers12102918.

56. Middleton JD, Stover DG, Hai T. Chemotherapy-Exacerbated Breast Cancer Metastasis: A Paradox Explainable by Dysregulated Adaptive-Response. Int J Mol Sci. 2018;19(11).

https://doi.org/10.3390/ijms19113333.

57. Yan L, Della Coletta L, Powell KL, Shen J, Thames H, Aldaz CM et al. Activation of the canonical Wnt/beta-catenin pathway in ATF3-induced mammary tumors. PLoS One. 2011;6(1):e16515. https://doi.org/10.1371/journal.pone.0016515.

58. Yin X, Wolford CC, Chang YS, McConoughey SJ, Ramsey SA, Aderem A et al. ATF3, an adaptiveresponse gene, enhances TGF $\{$ beta\} signaling and cancer-initiating cell features in breast cancer cells. $J$ Cell Sci. 2010;123(Pt 20):3558-65. https://doi.org/10.1242/jcs.064915.

59. Cao H, Yang ZX, Jiang GQ. Expression and clinical significance of activating transcription factor 3 in human breast cancer. Iran J Basic Med Sci. 2013;16(11):1151-4.

60. Zhao W, Sun M, Li S, Chen Z, Geng D. Transcription factor ATF3 mediates the radioresistance of breast cancer. J Cell Mol Med. 2018;22(10):4664-75. https://doi.org/10.1111/jcmm.13688.

61. Hasim MS, Nessim C, Villeneuve PJ, Vanderhyden BC, Dimitroulakos J. Activating Transcription Factor 3 as a Novel Regulator of Chemotherapy Response in Breast Cancer. Transl Oncol. 2018;11(4):988-98. https://doi.org/10.1016/j.tranon.2018.06.001.

62. Yin X, Dewille JW, Hai T. A potential dichotomous role of ATF3, an adaptive-response gene, in cancer development. Oncogene. 2008;27(15):2118-27. https://doi.org/10.1038/sj.onc.1210861.

63. Wortel IMN, van der Meer LT, Kilberg MS, van Leeuwen FN. Surviving Stress: Modulation of ATF4Mediated Stress Responses in Normal and Malignant Cells. Trends Endocrinol Metab. 2017;28(11):794806. https://doi.org/10.1016/j.tem.2017.07.003.

64. Nagelkerke A, Bussink J, Mujcic H, Wouters BG, Lehmann S, Sweep FC et al. Hypoxia stimulates migration of breast cancer cells via the PERK/ATF4/LAMP3-arm of the unfolded protein response. Breast Cancer Res. 2013;15(1):R2. https://doi.org/10.1186/bcr3373.

65. Dey S, Sayers CM, Verginadis, II, Lehman SL, Cheng Y, Cerniglia GJ et al. ATF4-dependent induction of heme oxygenase 1 prevents anoikis and promotes metastasis. J Clin Invest. 2015;125(7):2592-608. https://doi.org/10.1172/JCl78031.

66. Fan CF, Mao XY, Wang EH. Elevated p-CREB-2 (ser 245) expression is potentially associated with carcinogenesis and development of breast carcinoma. Mol Med Rep. 2012;5(2):357-62. https://doi.org/10.3892/mmr.2011.657. 
67. Gonzalez-Gonzalez A, Munoz-Muela E, Marchal JA, Cara FE, Molina MP, Cruz-Lozano M et al. Activating Transcription Factor 4 Modulates TGFbeta-Induced Aggressiveness in Triple-Negative Breast Cancer via SMAD2/3/4 and mTORC2 Signaling. Clin Cancer Res. 2018;24(22):5697-709. https://doi.org/10.1158/1078-0432.CCR-17-3125.

68. Snezhkina AV, Kudryavtseva AV, Kardymon OL, Savvateeva MV, Melnikova NV, Krasnov GS et al. ROS Generation and Antioxidant Defense Systems in Normal and Malignant Cells. Oxid Med Cell Longev. 2019;2019:6175804. https://doi.org/10.1155/2019/6175804.

69. Bai X, Ni J, Beretov J, Wasinger VC, Wang S, Zhu Y et al. Activation of the elF2alpha/ATF4 axis drives triple-negative breast cancer radioresistance by promoting glutathione biosynthesis. Redox Biol. 2021; 43:101993. https://doi.org/10.1016/j.redox.2021.101993.

70. Angelastro JM. Targeting ATF5 in Cancer. Trends Cancer. 2017;3(7):471-4. https://doi.org/10.1016/j.trecan.2017.05.004.

71. Hu M, Wang B, Qian D, Li L, Zhang L, Song X, et al. Interference with ATF5 function enhances the sensitivity of human pancreatic cancer cells to paclitaxel-induced apoptosis. Anticancer Res. 2012;32(10):4385-94.

72. Ishihara S, Yasuda M, Ishizu A, Ishikawa $M$, Shirato $H$, Haga $H$. Activating transcription factor 5 enhances radioresistance and malignancy in cancer cells. Oncotarget. 2015;6(7):4602-14. https://doi.org/10.18632/oncotarget.2912.

73. Persengiev SP, Green MR. The role of ATF/CREB family members in cell growth, survival and apoptosis. Apoptosis. 2003;8(3):225-8. https://doi.org/10.1023/a:1023633704132.

74. Ben-Shmuel S, Rashed R, Rostoker R, Isakov E, Shen-Orr Z, LeRoith D. Activating Transcription Factor5 Knockdown Reduces Aggressiveness of Mammary Tumor Cells and Attenuates Mammary Tumor Growth. Front Endocrinol (Lausanne). 2017; 8:173. https://doi.org/10.3389/fendo.2017.00173.

75. Li G, Li W, Angelastro JM, Greene LA, Liu DX. Identification of a novel DNA binding site and a transcriptional target for activating transcription factor 5 in c6 glioma and mcf-7 breast cancer cells. Mol Cancer Res. 2009;7(6):933-43. https://doi.org/10.1158/1541-7786.MCR-08-0365.

76. Dluzen D, Li G, Tacelosky D, Moreau M, Liu DX. BCL-2 is a downstream target of ATF5 that mediates the prosurvival function of ATF5 in a cell type-dependent manner. J Biol Chem. 2011;286(9):7705-13. https://doi.org/10.1074/jbc.M110.207639.

77. Monaco SE, Angelastro JM, Szabolcs M, Greene LA. The transcription factor ATF5 is widely expressed in carcinomas, and interference with its function selectively kills neoplastic, but not nontransformed, breast cell lines. Int J Cancer. 2007;120(9):1883-90. https://doi.org/10.1002/ijc.22469. 
78. Cubillos-Ruiz JR, Bettigole SE, Glimcher LH. Tumorigenic and Immunosuppressive Effects of Endoplasmic Reticulum Stress in Cancer. Cell. 2017;168(4):692-706.

https://doi.org/10.1016/j.cell.2016.12.004.

79. Madden E, Logue SE, Healy SJ, Manie S, Samali A. The role of the unfolded protein response in cancer progression: From oncogenesis to chemoresistance. Biol Cell. 2019;111(1):1-17. https://doi.org/10.1111/boc.201800050.

80. McGrath EP, Logue SE, Mnich K, Deegan S, Jager R, Gorman AM et al. The Unfolded Protein Response in Breast Cancer. Cancers (Basel). 2018;10(10) : 344. https://doi.org/10.3390/cancers10100344.

81. Wu J, Rutkowski DT, Dubois M, Swathirajan J, Saunders T, Wang J et al. ATF6alpha optimizes longterm endoplasmic reticulum function to protect cells from chronic stress. Dev Cell. 2007;13(3):351-64. https://doi.org/10.1016/j.devcel.2007.07.005.

82. Sicari D, Fantuz M, Bellazzo A, Valentino E, Apollonio M, Pontisso I et al. Mutant p53 improves cancer cells' resistance to endoplasmic reticulum stress by sustaining activation of the UPR regulator ATF6. Oncogene. 2019;38(34):6184-95. https://doi.org/10.1038/s41388-019-0878-3.

83. Vinson C, Myakishev M, Acharya A, Mir AA, Moll JR, Bonovich M. Classification of human B-ZIP proteins based on dimerization properties. Mol Cell Biol. 2002;22(18):6321-35. https://doi.org/10.1128/MCB.22.18.6321-6335.2002.

84. Gozdecka M, Breitwieser W. The roles of ATF2 (activating transcription factor 2 ) in tumorigenesis. Biochem Soc Trans. 2012;40(1):230-4. https://doi.org/10.1042/BST20110630.

85. Goetz J, Chatton B, Mattei MG, Kedinger C. Structure and expression of the ATFa gene. J Biol Chem. 1996;271(47):29589-98. https://doi.org/10.1074/jbc.271.47.29589.

86. De Graeve F, Bahr A, Sabapathy KT, Hauss C, Wagner EF, Kedinger C et al. Role of the ATFa/JNK2 complex in Jun activation. Oncogene. 1999;18(23):3491-500. https://doi.org/10.1038/sj.onc.1202723.

87. Song F, Wei M, Wang J, Liu Y, Guo M, Li X et al. Hepatitis B virus-regulated growth of liver cancer cells occurs through the microRNA-340-5p-activating transcription factor 7-heat shock protein A member 1B axis. Cancer Sci. 2019;110(5):1633-43. https://doi.org/10.1111/cas.14004.

88. Guo HQ, Ye S, Huang GL, Liu L, Liu OF, Yang SJ. Expression of activating transcription factor 7 is correlated with prognosis of colorectal cancer. J Cancer Res Ther. 2015;11(2):319-23. https://doi.org/10.4103/0973-1482.148688.

\section{Tables}

Table 1. Comparison of ATFs transcript levels between breast cancer and normal tissues from Oncomine database. 


\begin{tabular}{|c|c|c|c|c|c|}
\hline & $\begin{array}{c}\text { Type of Breast Cancer verus Normal Breast } \\
\text { Tissue }\end{array}$ & $\begin{array}{l}\text { Fole } \\
\text { Change }\end{array}$ & $P$ Value & $t$ Test & $\begin{array}{l}\text { Source and/or } \\
\text { Reference }\end{array}$ \\
\hline ATF1 & NA & NA & NA & NA & NA \\
\hline ATF2 & NA & NA & NA & NA & NA \\
\hline ATF3 & NA & NA & NA & NA & NA \\
\hline ATF4 & NA & NA & NA & NA & NA \\
\hline \multirow[t]{2}{*}{ ATF5 } & medullary breast carcinoma & 1.977 & $1.87 \mathrm{E}-09$ & 7.862 & Curtis Breast \\
\hline & ductal breast carcinoma & 1.760 & 8.34E-05 & 4.148 & Richardson Breast \\
\hline \multirow[t]{12}{*}{ ATF6 } & tubular breast carcinoma & 1.780 & $2.05 \mathrm{E}-27$ & 14.887 & Curtis Breast \\
\hline & ductal breast carcinoma in situ & 1.751 & $1.79 \mathrm{E}-04$ & 5.398 & Curtis Breast \\
\hline & invasive ductal and invasive lobular breast & 1731 & $339 E_{-} 33$ & 15609 & Curtis Breast \\
\hline & carcinoma & & & & \\
\hline & breast carcinoma & 1.630 & $1.33 \mathrm{E}-05$ & 0.067 & Curtis Breast \\
\hline & medullary breast carcinoma & 1.618 & $6.72 \mathrm{E}-08$ & 6.59 & Curtis Breast \\
\hline & invasive ductal breast carcinoma & 1.613 & $3.71 \mathrm{E}-66$ & 24.661 & Curtis Breast \\
\hline & invasive lobular breast carcinoma & 1.591 & $2.16 \mathrm{E}-38$ & 15.291 & Curtis Breast \\
\hline & invasive breast carcinoma & 1.570 & $2.53 \mathrm{E}-09$ & 8.657 & Curtis Breast \\
\hline & invasive breast carcinoma in situ epithelia & 1.750 & $2.00 \mathrm{E}-03$ & 3.554 & Ma breast \\
\hline & ductal breast carcinoma in situ epithelia & 1.986 & $3.28 \mathrm{E}-06$ & 6.319 & Ma breast \\
\hline & invasive ductal breast carcinoma & 4.518 & 0.002 & 4.058 & Radvanyi Breast \\
\hline
\end{tabular}




\begin{tabular}{|c|c|c|c|c|c|}
\hline \multicolumn{6}{|c|}{ invasive lobular breast carcinoma } \\
\hline & invasive mixed breast carcinoma & 6.122 & 8.60E-04 & 5.011 & Radvanyi Breast \\
\hline & invasive lobular breast carcinoma & 1.593 & $6.04 \mathrm{E}-11$ & 8.04 & TCGA Breast \\
\hline & invasive breast carcinoma & 1.666 & $2.56 \mathrm{E}-21$ & 11.362 & TCGA Breast \\
\hline & invasive ductal and lobular carcinoma & 1.974 & 4.21E-11 & 21.159 & TCGA Breast \\
\hline & mixed lobular and ductal breast carcinoma & 1.574 & $1.00 \mathrm{E}-03$ & 4.771 & TCGA Breast \\
\hline & invasive ductal breast carcinoma & 1.562 & $2.24 \mathrm{E}-29$ & 14.442 & TCGA Breast \\
\hline \multirow[t]{3}{*}{ ATF7 } & invasive ductal and lobular carcinoma & 1.557 & $2.63 \mathrm{E}-06$ & 6.539 & TCGA Breast \\
\hline & invasive breast carcinoma in situ epithelia & 1.616 & $3.00 \mathrm{E}-03$ & 3.326 & Ma breast \\
\hline & ductal breast carcinoma in situ epithelia & 1.918 & 2.07E-04 & 4.637 & Ma breast \\
\hline
\end{tabular}

Figures 


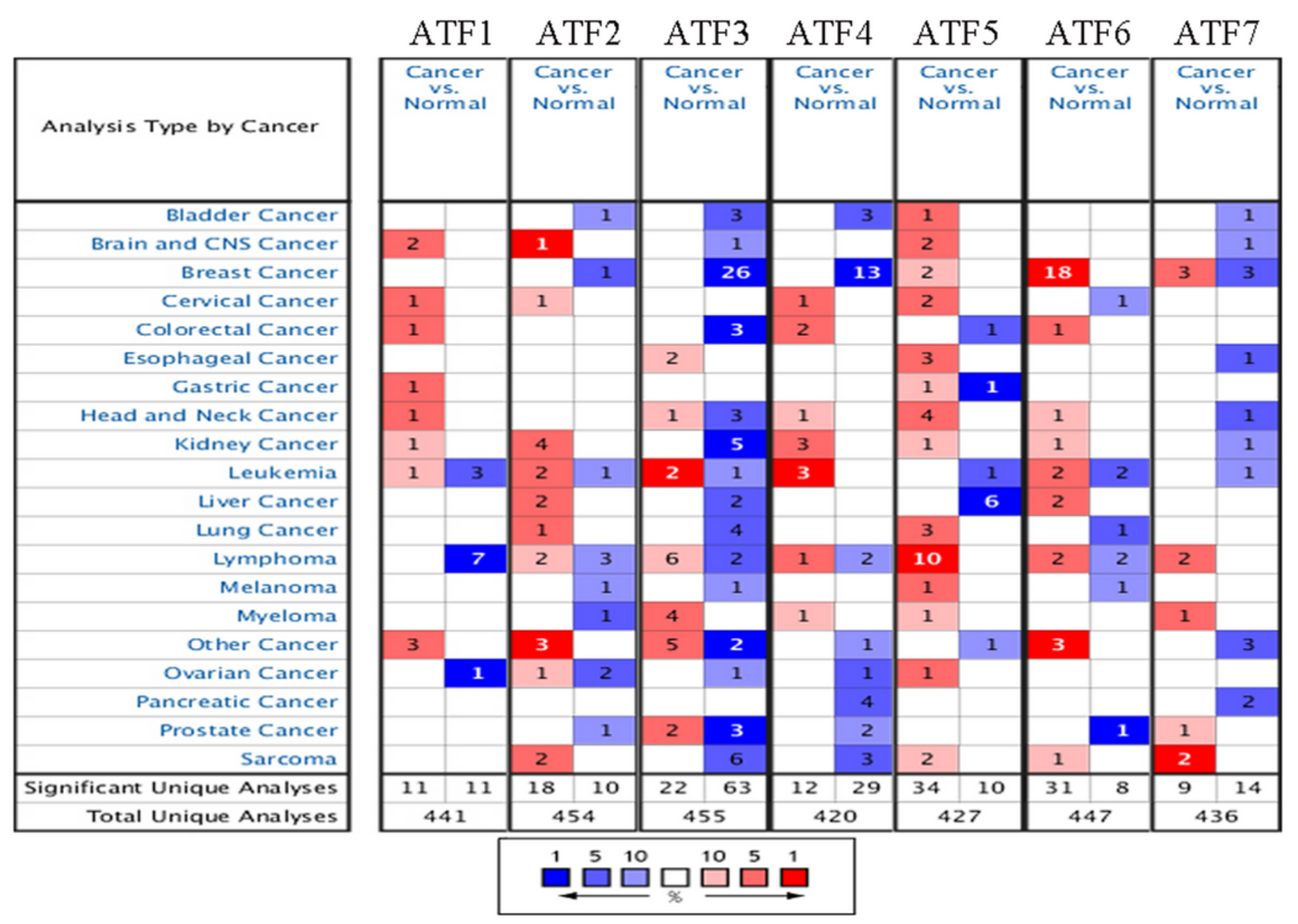

Figure 1

ATFs transcript levels in different tumor types (Oncomine). 

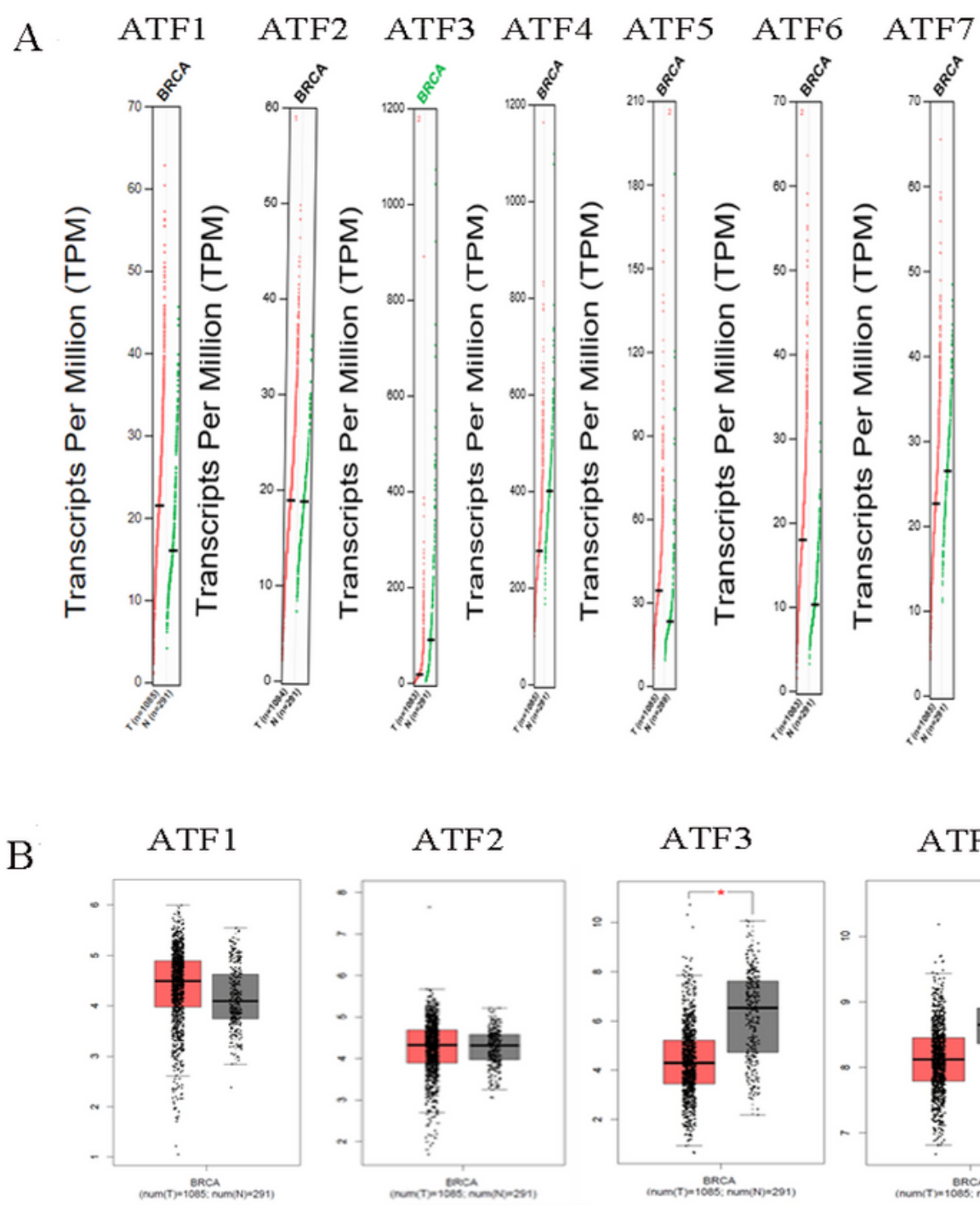

ATF3

ATF4

ATF5
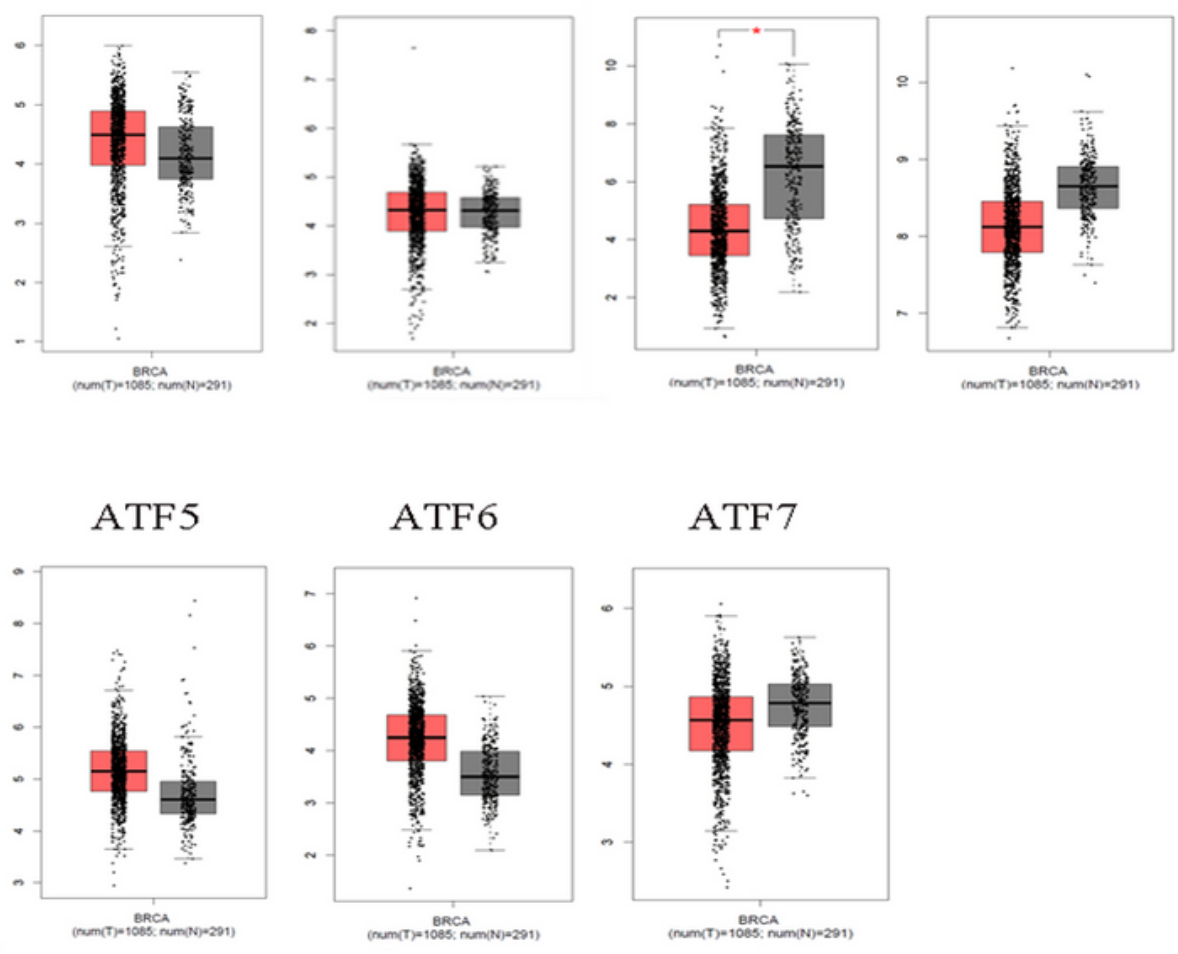

ATF 7

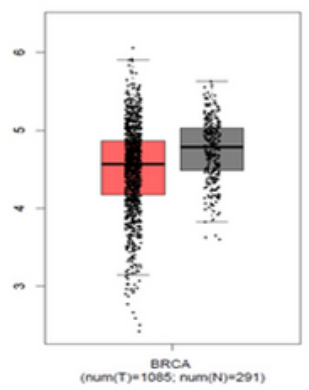

Figure 2

Comparison of ATFs transcript levels in BrCa and normal tissues (GEPIA). A, scatter diagram; B, box plot. 

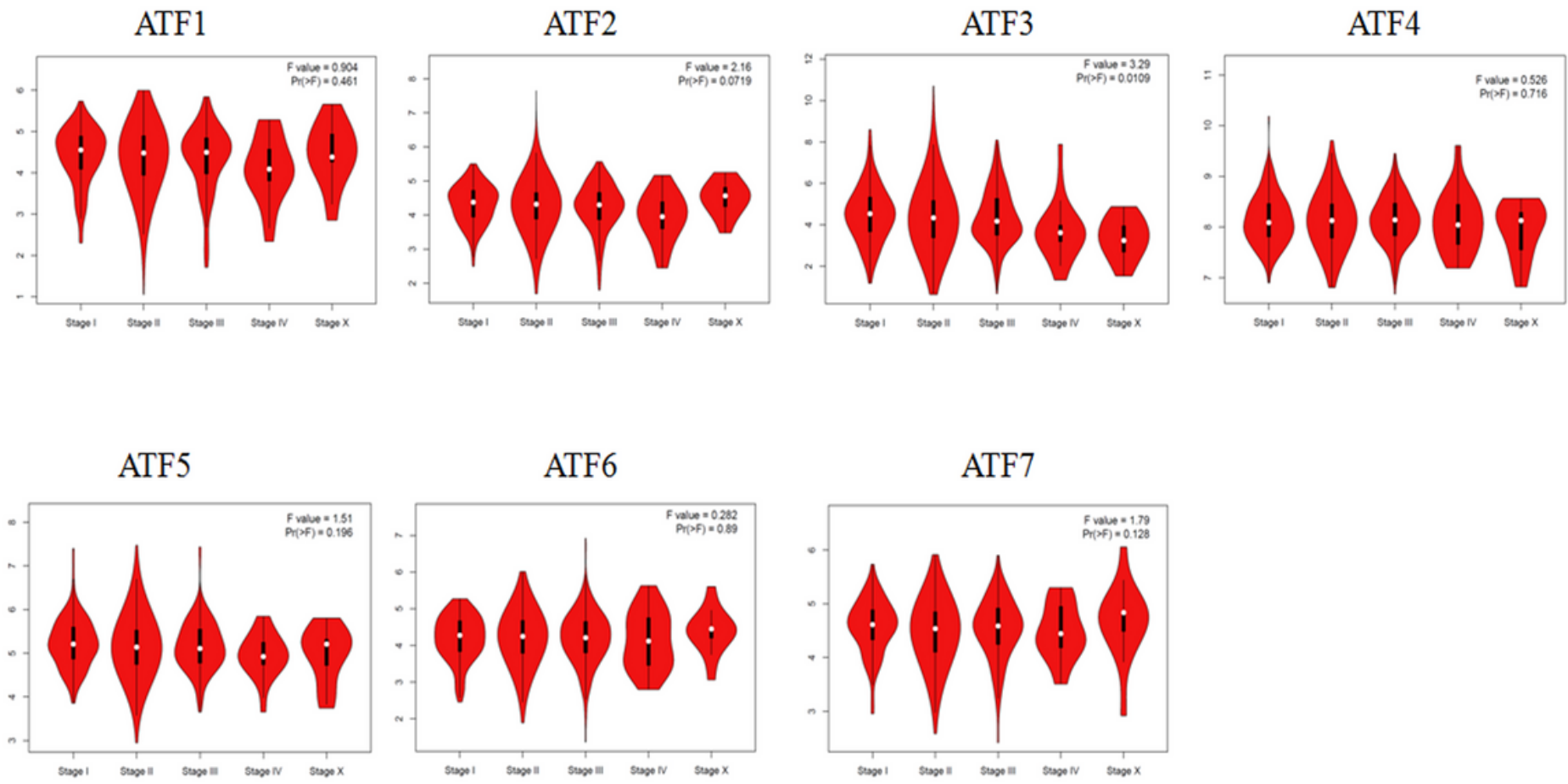

Figure 3

The relationship between the mRNA levels of ATFs and the stage of $\mathrm{BrCa}$ (GEPIA). 

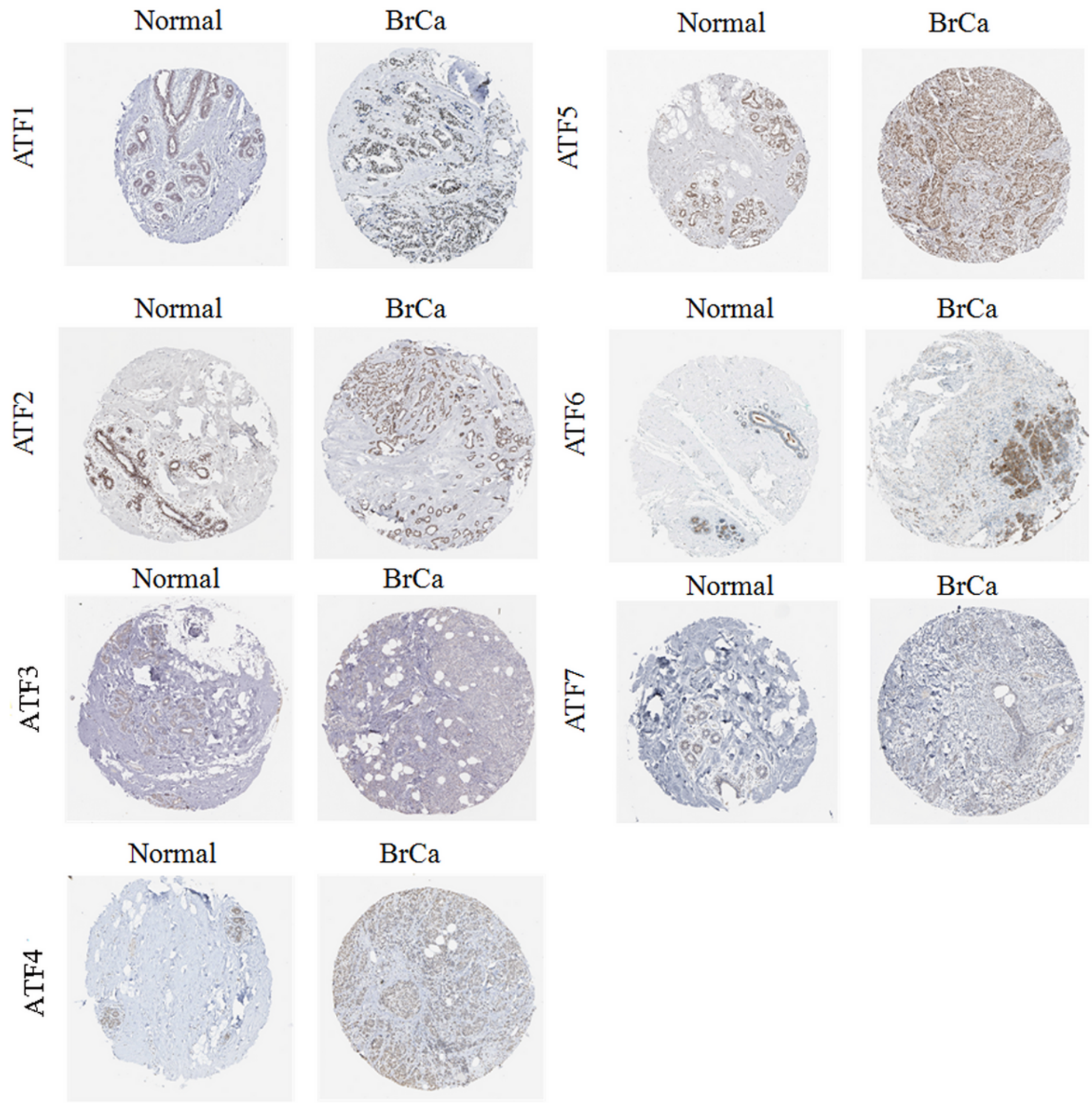

\section{Figure 4}

The expression levels of ATFs proteins in $\mathrm{BrCa}$ and normal tissues by immunohistochemical staining (The Human Protein Atlas). 

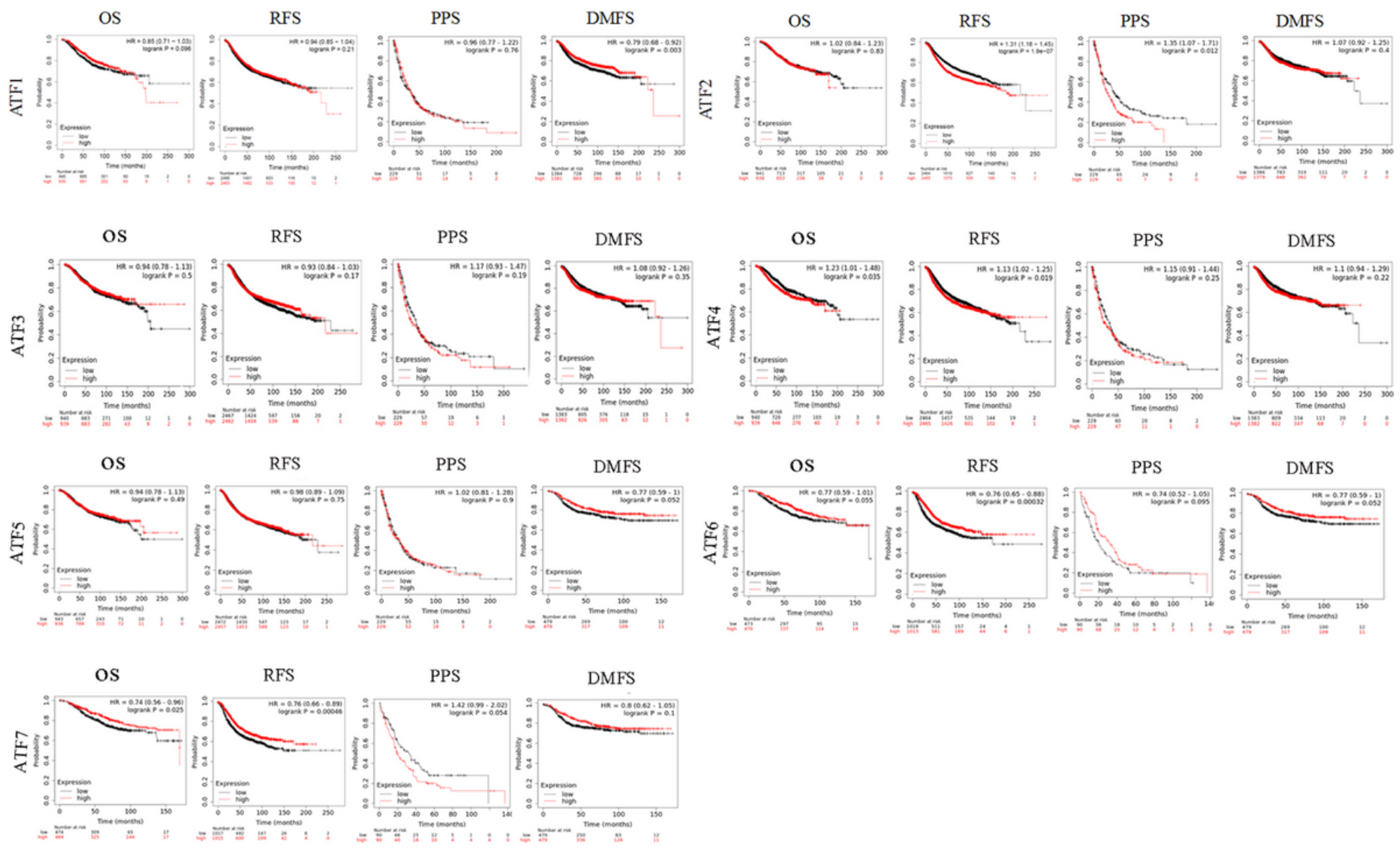

\section{Figure 5}

The correlation between the ATFs expression levels and the prognosis of BrCa patients (Kaplan-Meier Plotter).

A

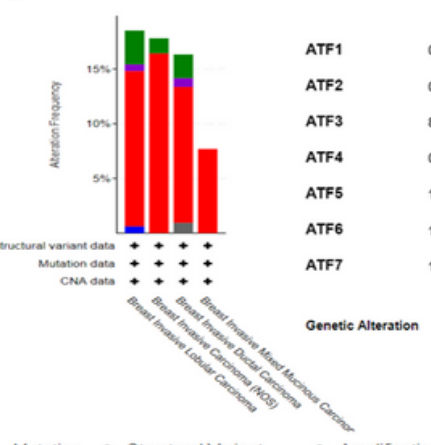

\section{Altered in $165(17 \%)$ of queried patients/samples}

0.5 0.8\%

8\%

.8.5

1.3\%

10\%

1\%

B

\begin{tabular}{|l|c|c|c|c|c|c|c|}
\hline & ATF1 & ATF2 & ATF3 & ATF4 & ATF5 & ATF6 & ATF7 \\
\hline ATF1 & 1 & 0.4 & -0.01 & -0.3 & -0.22 & 0.37 & 0.45 \\
\hline ATF2 & 0.4 & 1 & -0.04 & -0.34 & -0.23 & 0.42 & 0.45 \\
\hline ATF3 & -0.01 & -0.04 & 1 & 0.01 & -0.01 & -0.04 & 0.02 \\
\hline ATF4 & -0.3 & -0.34 & 0.01 & 1 & 0.35 & -0.35 & -0.41 \\
\hline ATF5 & -0.22 & -0.23 & -0.01 & 0.35 & 1 & -0.25 & -0.28 \\
\hline ATF6 & 0.37 & 0.42 & -0.04 & -0.35 & -0.25 & 1 & 0.41 \\
\hline ATF7 & 0.45 & 0.45 & 0.02 & -0.41 & -0.28 & 0.41 & 1 \\
\hline
\end{tabular}


Figure 6

Mutation type of ATF gene in BrCa (cBioPortal). (A) Summary of alternations of ATFs in BrCa. (B) Correlations of ATFs with other family members; Pearson's coefficients were presented.

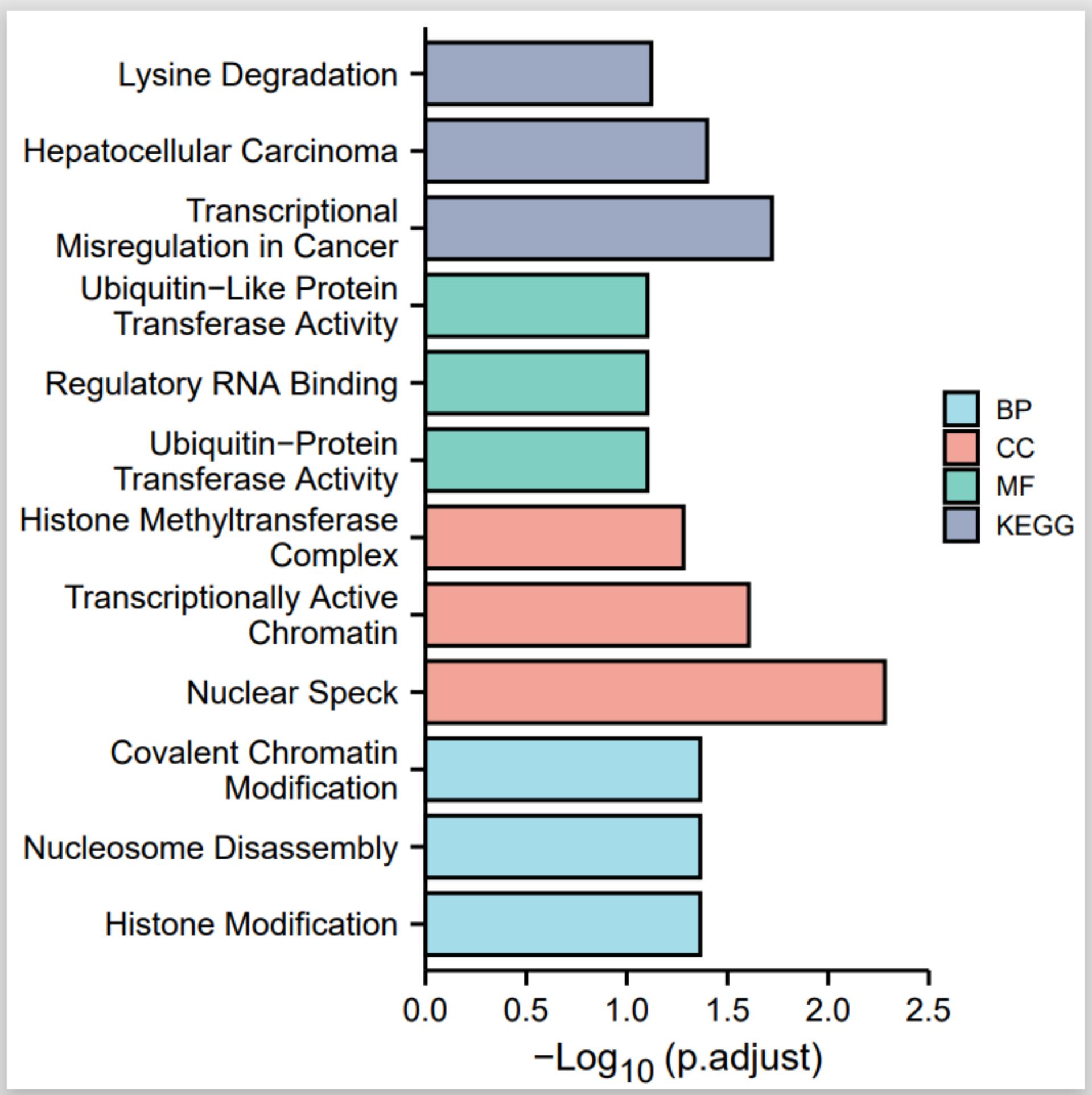

Figure 7

The functions of ATFs and genes mutated with ATFs (GO enrichment and KEGG pathway analysis). 
A

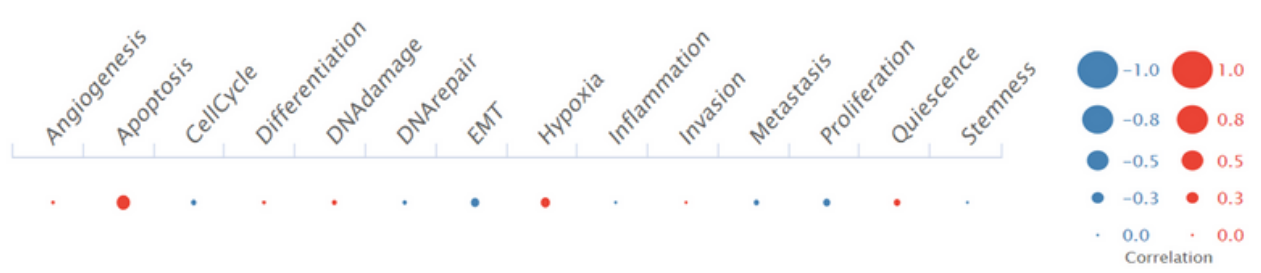

B

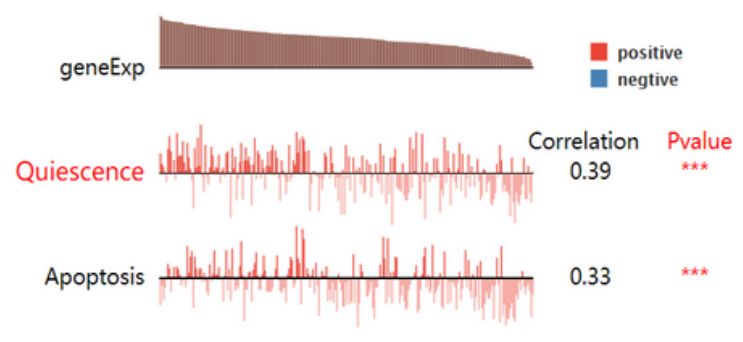

$\mathrm{C}$

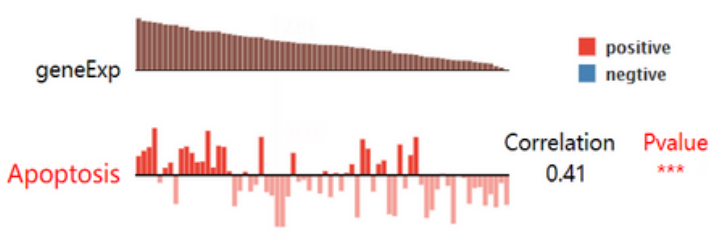

$\mathrm{D}$

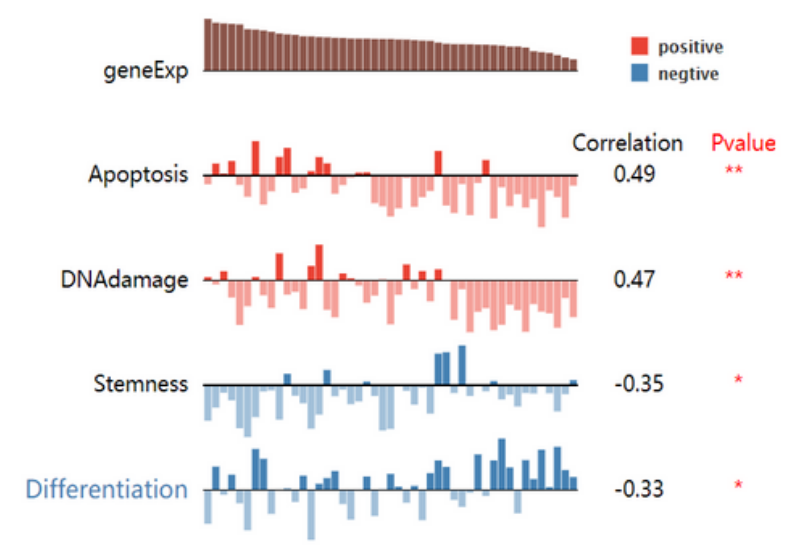

\section{Figure 8}

Functional analysis of ATFs in BrCa (CancerSEA). (A) Correlated functions of ATFs in BrCa patients; blue bubble represents negatively correlated, red bubble represents positively correlated, bubble size represents the average correlation strength. Detailed functional correlations in $\mathrm{BrCa}$ chip $(\mathrm{B}, \mathrm{C})$ and in different cell groups(D). ${ }^{\star * * P} \leq 0.001,{ }^{\star *} P \leq 0.01$, and ${ }^{*} P \leq 0.05$. 